\title{
About Clostridium botulinum, Fish and Tilapia
}

\author{
Alejandro De Jesús Cortés-Sánchez ${ }^{1}$ \\ ${ }^{1}$ Consejo Nacional de Ciencia y Tecnología (CONACYT). Unidad Nayarit del Centro de Investigaciones \\ Biológicas del Noroeste (UNCIBNOR+). Calle Dos No. 23. Cd. del Conocimiento. Av. Emilio M. González. Cd. \\ Industrial. C.P. 63173. Tepic, Nayarit, México \\ Correspondence: Alejandro De Jesús Cortés-Sánchez. Consejo Nacional de Ciencia y Tecnología (CONACYT). \\ Unidad Nayarit del Centro de Investigaciones Biológicas del Noroeste (UNCIBNOR+). Calle Dos No. 23. Cd. \\ del Conocimiento. Av. Emilio M. González. Cd. Industrial. C.P. 63173. Tepic, Nayarit, México. E-mail: \\ alecortes_1@hotmail.com ORCID ID 0000-0002-1254-8941
}

Received: March 4, 2021

doi:10.5539/mas.v15n3p1
Accepted: April 6, 2021

Online Published: April 8, 2021

\begin{abstract}
Fish and products are considered a food of nutritional quality that constituents a part of the human diet, produced and commercialized worldwide. Tilapia is one of the main fish for aquaculture production destined for human consumption in different presentations: refrigerated, frozen, fillet, cured, canned, among others. Fish, in addition to being a highly nutritious food, is also sensitive to deterioration and contamination along the food chain, being able to be contaminated mainly by microorganisms that are casual agents of consumer illnesses. Clostridium botulinum and spores can contaminate foods such as fish and products whose germination, growth and generation of botulinum toxin puts the health of consumers at high risk of acquiring botulism disease, which is of importance in public health due to its incidence and high fatality rate. This review describes in a general way the aspects related to fish and tilapia, foodborne diseases such as botulism, the causal agent, in addition to sanitary regulation, control and prevention of contamination of food products to protect food safety, and consumer's health.
\end{abstract}

Keywords: Anaerobic mesophiles, canned food, cured food, food pathogens

\section{Introduction}

The search for a nutritious, healthy, and balanced diet requires a wide variety of foods. Among the options in the food selection is fish, a food generally suitable for all ages, easily digested, and container of proteins of high biological value as it is a source of essential amino acids, lipids, vitamins, and minerals (Traverso \& Avdalov, 2014). The availability of nutritious and safe food in sufficient proportion is essential to preserve life and promote health (WHO, 2021). Food safety is the property that it will not cause harm or illness to the consumer (De la Fuente \& Corona, 2010; Fuertes et al., 2014).

Food safety is considered, along with the nutritional, organoleptic, and commercial characteristics, constituents of the total quality of food (De la Fuente and Corona, 2010). Due to the relationship that exists between safety, production technologies, food handling and consumer health, its importance and obtention are fundamental and undeniable (De la Fuente \& Corona, 2010; Palomino-Camargo \& González-Muñoz, 2014; Fuertes et al., 2014).

Through the different phases of the food chain (from farm to table), a food can be contaminated by different causal agents, mainly of biological origin (bacteria, viruses, fungi, parasites, and prions) or chemical (natural toxins, compounds organic and heavy metals), losing their safety and putting the health of consumers at risk (De la Fuente \& Corona, 2010; Guerrero et al., 2016; Huertas-Caro et al., 2019; WHO, 2021). It has been established that among the main causes that result in the contamination of products along the food chain are related to inadequate or absent hygiene conditions and practices, control of inappropriate thermal processes, high degree of handling, and use of water or contaminated raw material (Rodríguez-Cavallini et al., 2010; De la Fuente \& Corona, 2010; Guerrero et al., 2016; Huertas-Caro et al., 2019; WHO, 2021).

The purpose of this document is to provide academics, the food industry and the general public a review with a generalized perspective of information obtained in different databases (Scielo, Scopus, Redalyc among other) on topics such as: foodborne diseases with a focus on botulism, characteristics of the causal agent, food susceptible to contamination and related to disease, especially fish and products. It also includes actions for the prevention 
and control of contamination in food, including laboratory analysis and the different existing sanitary regulations around the world. All of the above in order to spread knowledge, raise awareness and guarantee safety in food production and public health.

\section{Foodborne Diseases}

Foodborne diseases are the product of the consumption of contaminated water or food with physical, chemical or microbiological agents in quantities that affect the health of the consumer; these diseases are considered a public health problem at a global level due to their morbidity and mortality, as well as the negative effects on the economy, trade, productivity and high costs in health services (Palomino-Camargo \& González-Muñoz, 2014; Rodríguez et al., 2015; Guerrero et al., 2016; Huertas-Caro et al., 2019).

It is estimated that each year these diseases affect one in ten people and 420,000 people die worldwide, especially children (WHO, 2021). In the United States of America, 48 million people are reported to become ill annually due to food consumption resulting in 128,000 hospitalizations and 3000 deaths (CDC, 2018). The main susceptible groups of these diseases are the elderly, children, the immunocompromised and people subjected to high levels of poverty and unhealthy conditions (Rodríguez et al., 2015; Soto et al., 2016; CDC, 2019).

In recent years the incidence of these diseases around the world has increased, and that is considered due to factors such as globalization, international food trade, new processing technologies, social migration, changes in eating habits, increased life expectancy, climate change, appearance of microorganisms better adapted to resist stress conditions, antibiotics favoring the spread, re-emergence, and appearance of pathogenic microorganisms (Palomino-Camargo \& González-Muñoz, 2014; Masana, 2015; Donoso et al., 2016; Huertas-Caro et al., 2019; López et al., 2020).

More than 250 contaminating agents have been reported as causals of diseases through food, being those of biological origin, such as prions, parasites, viruses, fungi and bacteria, the main ones related; having the bacteria ones frequently associated with cases or outbreaks of diseases in consumers, as well as food spoilage (Alerte et al., 2012; Rodríguez et al., 2015; Soto et al., 2016; Huertas-Caro et al., 2019).

Foodborne diseases caused by bacteria are classified into two groups: I) Infections, where microorganisms multiply or lyse within the gastrointestinal tract, presenting two variants: A) Invasive infections: characterized by the microorganism colonizing tissues and organs of the affected person, having as examples: Salmonella spp., Aeromonas spp., Campylobacter spp., Shigella spp., Vibrio parahaemolyticus, Yersinia spp., and Enteroinvasive Escherichia coli (EIEC); and B) Toxi-infections: caused by bacteria capable of colonizing and multiplying in the host's intestinal tract, where they excrete their toxins, as is the case of: Vibrio cholerae, Bacillus cereus (enterotoxin-producing strains), Clostridium botulinum, Clostridium perfringens and the enteropathogenic variants of Escherichia coli that produce enterotoxins, or verotoxins; and II) Intoxication caused by microbial growth and production of toxins in food, being examples of such the Bacillus cereus, Staphylococcus aureus and Clostridium botulinum (Rodríguez et al., 2015; Cortés-Sánchez et al., 2015; Guerrero et al., 2016; Huertas-Caro et al., 2019).

Foodborne diseases have a wide range of gastrointestinal symptoms, including nausea, vomiting, diarrhea, abdominal pain, and fever, and in some cases, it can present severe complications such as sepsis, meningitis, abortions, Reiter's syndrome, Guillain-Barré syndrome, cancer, and even death (Soto et al., 2016; WHO, 2021). The foods associated with the transmission of diseases are varied, being those that, due to their intrinsic characteristics, present a greater susceptibility to contamination and bacterial proliferation, like the ones with a high protein content, water activity, or $\mathrm{pH}$ hovering around neutrality, such as meat, fish, egg, milk, and derivatives, being these considered of high risk (Alerte et al., 2012; Rodríguez et al., 2015).

\section{Fish}

It is called "fish" to any food extracted from oceanic or continental waters intended for human or animal nutrition (Davalos et al., 2005; Soares \& Gonçalves, 2012). It is considered in the human diet as a highly nutritious source of proteins, with a high digestibility and biological value, polyunsaturated lipids, minerals, water-soluble, and fat-soluble vitamins (Huss, 1998; Davalos et al., 2005; Soares \& Gonçalves, 2012; Fuertes et al., 2014).

Fish production is through capture fisheries and aquaculture activities, where the joint production was 178.5 million tons worldwide, with 156.4 million tons being destined mainly for human consumption, with a per capita consumption of $20.5 \mathrm{~kg}$. Fish and fishery products are among the most commercialized food products in different presentations around the world, whether fresh, frozen, canned, dry, salted, smoked, pickled, among others (Davalos et al., 2005; FAO, 2020). 
Fish, as a food, presents a high susceptibility to deterioration mainly due to enzymatic (autolysis), oxidative and microbial activity, its almost neutral $\mathrm{pH}$, high water activity in tissues, content of nutrients assimilated by microorganisms, and high content of phospholipids; therefore, their quality, useful lifetime, and safety are in direct correlation with factors such as the species, environment where they live, capture method, handling, processing and conservation conditions (Huss, 1998; Davalos et al., 2005; Soares \& Gonçalves, 2012; Fuertes et al., 2014; Rabiela, 2015).

\subsection{Tilapia}

Tilapia is one production and commercial fish. Other species of freshwater fish originating in Africa that belong to the Cichlidae family are under the name "Tilapia" and are classified into three genera according to parental care patterns in: Oreochromis, Tilapia and Sarotherodon (Baltazar, 2007; Jacome et al., 2019).

The genus Oreochromis $(O$. niloticus, $O$. aureus, $O$. mossambicus), and interspecific hybrids, are considered suitable as aquaculture production organisms because they tolerate high densities, are easy to reproduce, have a fast growing, are resistant to diseases, are adaptable to captivity, accept balanced feeding diets, and their meat is of good quality and affordable price, being one of the most commercialized aquaculture fish in the international market, either in full product or fillet presentation (Baltazar, 2007; Jacome et al., 2019). It is estimated that the aquaculture production of Tilapia (O. niloticus) was $8.3 \%$ of the total finfish species in 2018 worldwide, having some Asian countries as the largest producers (China, India, Indonesia, Vietnam, Bangladesh, among others) (FAO, 2020).

In countries like Mexico, the aquaculture contributes $91 \%$ of Tilapia production, being extensive, intensive and semi-intensive according to the planting density, food supply and type of farming system. The species produced are: 1) Herbivorous Tilapia (Tilapia rendalli); 2) Nile Tilapia (Oreochromis niloticus); 3) Stirling Tilapia (O. niloticus Var. Stirling); 4) White Tilapia, Blue Tilapia, (O. niloticus Var. Rocky Mountain); 5) Mozambique Tilapia, (O. aureus, O. mossambicus); 6) Orange Tilapia, (O. mossambicus Var. Orange); 7) Mojarra Tilapia (O. urolepis hornorum), and 8) Red Tilapia from Florida Oreochromis sp. (O. mossambicus $x$ O. urolepis hornorum) hybrid (SAGARPA, 2018; INP, 2018). Tilapia production is within the 10 most cultivated species with 52,748 tons, only behind shrimp. The largest producers are states of Chiapas, Tabasco, Guerrero, Michoacán, Sinaloa, Jalisco, State of Mexico, and Veracruz (SAGARPA, 2018; Martínez et al., 2021). Worldwide, Mexico ranks fifth in production under controlled systems, and ninth through fish production (SAGARPA, 2018). The average weight is $250 \mathrm{~g}$ to $700 \mathrm{~g}$, and its presentation of the product is generally fresh whole gutted, whole frozen gutted, fresh or frozen fillet, with Tilapia having an annual per capita consumption of $2 \mathrm{~kg}$ (SAGARPA, 2018; INP, 2018).

\section{Clostridium spp.}

The genus Clostridium belongs to the family Clostridiaceae, they are Gram-positive microorganisms in the form of bacilli, are anaerobic, present fimbriae, form spores and toxins, many of them being of importance in the food industry and health (Elika, 2013; Hernández Urzua, 2016; Cortés-Sánchez, 2018). Among the metabolic characteristics of the genus are that they are oxidase negative, most catalase and superoxide dismutase (SOD) negative, grow at a temperature of $37^{\circ} \mathrm{C}$, the minimum water activity (aw) for their development is 0.95 , and at a $\mathrm{pH}$ between 7 and 7.4, these bacteria are widely distributed in nature, most of them with saprophytic existence in the soil, dust, sediments, aquatic environment, and in the gastrointestinal tract of humans and animals, forming part of the microbiota; their spores can survive in hostile environments for long times, most of species are proteolytic, sugar fermenters and various species such as Clostridium difficile, Clostridium botulinum, Clostridium perfringens, Clostridium clostridioforme and Clostridium malenominatum can be in free "planktonic" form, or form aggregates such as "biofilms", as well as survival and virulence mechanism, and the generation of extracellular exotoxins and enzymes (Pelczar et al., 1982; Elika, 2013; Pantaléon et al., 2014; ANMAT, 2014; Hernández Urzua, 2016; Cortés-Sánchez, 2018;). The most important species from the perspective of food and human health are: C. botulinum, C. perfringens, $C$. tetani and $C$. difficile associated with food consumption and intoxications (Elika, 2013; ANMAT, 2014; Cortés-Sánchez, 2018).

\subsection{Clostridium botulinum}

Clostridium botulinum is a Gram-positive bacillus, mobile with peritrichous flagella, terminal or subterminal oval spores, non-capsulated, 3 to $8 \mu \mathrm{m}$ long x 0.5 to 1.3 wide, strictly anaerobic, fermenting glucose, does not reduce nitrates, generates hydrogen sulfide, has growth at $\mathrm{pH}$ of 7.2 to 7.4 , and an optimum temperature for growth and botulinum toxin production of $35-40^{\circ} \mathrm{C}$ that affects humans and animals likewise (Pelczar et al., 1982; Romero, 1999; Pérez et al., 2003; Hernández Urzua, 2016; Elika, 2020). There are seven subtypes of $C$. botulinum, according to the antigenic characteristics of the botulinum toxin they produce, being identified with 
the letters from "A" to "G" (Pérez et al., 2003; Cereser et al., 2008; Hernández Urzua, 2016; Elika, 2020). Types $\mathrm{A}, \mathrm{B}, \mathrm{E}, \mathrm{F}$ and $\mathrm{G}$ can cause human botulism, while types $\mathrm{A}, \mathrm{B}$ and $\mathrm{E}$ are the most frequent and toxic (Perez et al., 2003; Hernández Urzua, 2016; Elika, 2020).

C. botulinum is also classified into four groups (I-IV) in relation to its 16S rRNA gene, metabolic and biochemical properties, specifically with its proteolytic capacity (Rosaura et al., 2011; González-Escalona et al., 2014). The C. botulinum strains that produce botulism in humans belong to groups I (proteolytic strains that produce toxins A, B, and F), and group II (non-proteolytic strains that produce toxins B, F, and E) (Rosaura et al., 2011; González-Escalona et al., 2014). Meanwhile, botulism among animals is usually caused by strains of group III, which produce toxins $\mathrm{C}$ and $\mathrm{D}$, and finally group IV that generates toxin $\mathrm{G}$, little studied though related in cases of human and/or animal botulism (González-Escalona et al., 2014).

It has been established that the lethal dose of botulinum toxin A for an average $70 \mathrm{~kg}$ human being orally taken is $70 \mu \mathrm{g}, 0.09$ to $0.15 \mu \mathrm{g}$ intravenous or intramuscular and 0.70 to $0.90 \mu \mathrm{g}$ by inhalation (Cereser et al., 2008; González-Escalona et al., 2015). Due to its high toxicity, botulinum toxins present a significant risk to humans and are considered a potential biological warfare agent, being listed as a category A high-risk threat by the US Centers for Disease Control and Prevention (CDC) (González-Escalona et al., 2015). C. botulinum toxins are antigenically and immunologically different, with a chemically related protein structure, and a molecular weight between 140 and $170 \mathrm{kDa}$, produced in the growth phase and released during bacterial lysis (Romero, 1999; Pérez et al., 2003; Bratz \& Mallet, 2015). The toxins consist of three fractions that when hydrolyzed, have different functions in the process of cell intoxication and functional blockage. The fraction $\mathrm{Hc}$ is responsible for the connection with the motor neuron; the fraction $(\mathrm{Hn})$ is responsible for the internalization and translocation of the membrane of nerve cells and the light chain $(\mathrm{L})$ that is the active form of the toxin, a catalytic portion that inhibits the exocytosis of acetylcholine-containing synaptosomes (Bratz \& Mallet, 2015).

All toxins are sensitive to alkalis and heat at $80^{\circ} \mathrm{C}$ for 30 minutes, at $100^{\circ} \mathrm{C}$ for 5 minutes, sunlight for 1 to 3 hours, and room temperature for 12 hours or 20 minutes in chlorinated water with $84 \%$ destruction, but they are resistant to digestive acids and enzymes (Pelczar et al., 1982; Cereser et al., 2008). On the other hand, despite being considered high biological risk toxins, they present therapeutic applications in the treatment of different disorders of muscle spasms, in addition to different purposes in cosmetics and aesthetics (Pérez et al., 2003; Gonzalez-Escalona et al., 2014; Bratz \& Mallet, 2015).

\section{Botulism}

Botulism is the disease caused by Clostridium botulinum and the generation of neurotoxins. So far, four forms of botulism have been reported: 1) Foodborne botulism, derived from ingestion of the preformed toxin in contaminated food where the germination of spores in food is favored by anaerobic conditions (packaged or sealed food), $\mathrm{pH}>4.5$ and high water activity, therefore vegetative cells produce the toxin in the container during storage; 2) Wound botulism (toxin production in vivo in contaminated wounds); 3) Infant botulism (spore ingestion and toxin production in the infant's intestine); and 4) Indeterminate, which includes cases of older children and adults, where the disease occurs by a mechanism similar to that of children (Pérez et al., 2003; Cereser et al., 2008).

Foodborne botulism is the most frequent in countries where home-made food is prepared, since the sources of contamination are unknown, and are subjected to inadequate storage conditions (Romero, 1999). Botulinum toxin is one of the most powerful toxins in nature; when it is consumed in contaminated food, even in exceedingly small doses, it generates botulism, an intoxication that is rare, yet with serious consequences that affect the nervous and muscular systems, produces respiratory failure, which can be lethal in some cases $(1-10 \%)$ (Madigan et al., 2004; Elika, 2013; Huertas-Caro et al., 2019; Elika, 2020). According to estimates of the European Food Safety Authority and European Center for Disease Prevention and Control (EFSA and ECDC), it was reported that in $2017,16.1 \%$ of outbreaks of foodborne diseases in member states of the European Union were due to bacterial toxins coming from a proportion of C. botulinum, and were responsible for $0.2 \%$ of the total outbreaks of foodborne diseases, with 9 outbreaks of illnesses, involving 26 people where all required hospital care, and having 2 deaths $(7.7 \%)$. Therefore, it has a high mortality with respect to the rest of foodborne diseases and different causative agents (EFSA / ECDC, 2018).

There are 2 ways of transmission of botulism through food: A) Botulinum poisoning, due to the ingestion of preformed toxin in food, which is common in adults; and B) Botulinum toxi-infection, derived from the ingestion of bacteria and/or spores, mainly by babies under 1 year of age, which, due to the immaturity of their digestive system, it germinates, colonizes the intestine, and releases toxin. Therefore, the children under 1 year of age are a group of risk (Pérez et al., 2003; Elika, 2013; Elika, 2020). 
Symptoms of the disease may appear in between 12 and 36 hours after the ingestion of contaminated food, showing severe fatigue, weakness, vertigo, blurred vision, headache, dry mouth and difficulty swallowing and speaking, vomiting, diarrhea and abdominal swelling, weakness in the neck and arms, and subsequent alterations in the respiratory muscles and the lower part of the body, causing death from respiratory failure and/or cardiac arrest (Pelczar et al., 1982; Pérez et al., 2003; Hernández-Urzua, 2016; Elika, 2020).

Toxins interfere with neurotransmission in peripheral cholinergic synapses by binding themselves to the presynaptic membrane, preventing acetylcholine exocytosis, and causing muscle paralysis (Pérez et al., 2003; Hernández-Urzua, 2016; Elika, 2020). The mortality rate is high if an early diagnosis and adequate treatment, such as rapid administration of antitoxin and intensive respiratory care, are not carried out, and the recovery can be prolonged, and last, for months (Romero, 1999; Pérez et al., 2003; Tornese et al., 2008; Elika, 2020).

\section{Clostridium botulinum, Fish, and Tilapia}

For fishery and aquaculture products, quality is mainly related to the degree of freshness (Davalos et al., 2005; Soares \& Goncalves, 2012; Rabiela, 2015). However, safety and public health aspects must also be considered for fish as well. In addition to being a very perishable food, it is susceptible to contamination along the food chain by different microorganisms responsible for deterioration and being causal of diseases in human beings (Soares \& Goncalves, 2012; Rabiela, 2015; Novoslavskij et al., 2016).

Fish and products have been linked to cases and outbreaks of foodborne diseases around the world; these diseases being mainly caused by bacteria such as: Salmonella spp., Shigella spp., Vibrio spp., E. coli, S. aureus, Clostridium botulinum, and toxins (Vasquez, 2003; Alerte et al., 2012; Espinosa et al., 2014).

In a natural way, microorganisms in fish vary considerably and can be in the skin, gills, and intestines of live and freshly caught fish, where their total proportion varies greatly between $10^{2}$ and $10^{9} \mathrm{CFU} / \mathrm{g}$. The muscle of a healthy or freshly caught fish is sterile, because its immune system prevents the growth of bacteria in the muscle, but when the fish dies, this system collapses and the bacteria proliferate, invade, and freely colonize the muscle, penetrating in between the muscle fibers (Huss, 1998; Novoslavskij et al., 2016).

Fish have a microbiota that is dependent on the aquatic environment, water quality, food, temperature, season of the year where they live, and they are considered potential carriers of pathogenic bacteria transmitted to humans by food (Huss, 1998; Romero-Jarero \& Negrete-Redondo, 2011; Novoslavskij et al., 2016; Sheyin \& Solomon, 2017). Bacteria present in fish can be from one of two groups: 1) Autochthonous bacteria that are widely distributed in aquatic environments in different parts of the world, where water temperature has a selective effect and represent part of the microbiota of fish. Among these type the C. botulinum, Listeria monocytogenes, Vibrio sp., Aeromonas sp., Plesiomonas shigelloides can be found; and 2) Non-autochthonous bacteria, such as E. coli, Salmonella spp., Shigella spp., Yersinia spp., Staphylococcus aureus, where their presence is associated to human and animal faecal contamination of aquatic environments, aquaculture, or through direct contamination of products during processing and handling (Huss, 1997; Romero-Jarero \& Negrete-Redondo, 2011; Santos e Oliveira, 2012; Novoslavskij et al., 2016).

In the case of $C$. botulinum, its prevalence in water sediments and fish can be influenced by several factors such as geographic location, feeding habits of the fish species, types of samples and detection method. Studies around the world have indicated the presence of different types of C. botulinum, such as A, B, E and F. Therefore, the aquatic bottom is considered a reservoir of $C$. botulinum, and it is suggested that fish and water currents can contribute to the spread of the pathogen (Novoslavskij et al., 2016).

The presence of $C$. botulinum in aquatic environments represents a risk because fish may host various toxigenic types and could be a threat to public health as a source of foodborne botulism. The presence of C. botulinum in fish may be associated to the direct contact with aquatic environments and ingestion of $C$. botulinum or spores present in contaminated sediments or feed, which already impact food safety, without considering the application of good hygiene practices in the processing and heat treatment of products for human consumption (Alerte et al., 2012; Espinosa et al., 2014; Novoslavskij et al., 2016).

In the case of microorganisms present in Tilapia, various studies have reported the presence of different Gram negative microbial groups such as: Pseudomonas, Psychrobacter, Shewanella, Flavobacterium, Pseudoalteromonas, Acinetobacter, Moraxella, Vibrio, Photobacterium, Aeromonas, among others, as well as Gram-positive ones such as: Micrococcus, Bacillus, Corynebacterium, Vagococcus, Streptococcus, and species of the genus Clostridium spp., as part of the microbiota detected in various organs such as skin, gills, intestines, fillets or muscle (Sheyin \& Solomon, 2017; Haygood et al., 2018; Duan et al., 2019; Garcia-Perez et al., 2021). These microbial groups have been indicated as contributors in the deterioration and sanitary quality of fish, and 
their presence is influenced by environmental conditions, cultivation, handling, processing, and storage (Fuentes et al., 2011; Monroy-Dosta et al., 2013; Daun et al., 2019; Garcia-Perez et al., 2021).

\section{Control and Prevention of Foodborne Botulism}

The development, implementation and strengthening of food control systems that include coordination, management, legislation, surveillance, supervision of laboratory services, inspection, education, information, and health communication throughout the food chain (from production up to retail sale), is established to reduce risks and cases of disease transmission through food, including those of hydrobiological origin and derivatives (Donoso et al., 2016; López et al., 2020).

The risk of food botulism can occur in different circumstances: 1) A food to be preserved becomes contaminated with spores. 2) When the preservation process does not inactivate spores, but destroys other spores that can inhibit the proliferation of $C$. botulinum, providing favorable conditions for the growth and production of toxins in foods, especially those with a high amount of protein, low salt concentration $(<8 \%)$, aw $>0.93$, slightly acidic or alkaline $\mathrm{pH}$ (higher than 4.6), temperatures between $3^{\circ} \mathrm{C}$ and $45-50^{\circ} \mathrm{C}$ and processed foods and vacuum packed or in a modified atmosphere with absence of oxygen such as the canned ones (Pérez et al., 2003; Tornese et al., 2008; Cereser et al., 2008; Elika, 2013). 3) In the case of packaged foods when they are not subjected to a high temperature for a certain period to inactivate Clostridium spores. Important to consider that toxins are relatively sensitive to heat and are inactivated by heating at $80^{\circ} \mathrm{C} / 10$ minutes and in industrial canning at $120^{\circ} \mathrm{C}$ / 4 minutes. 4) When the cold chain is not taken care of during the transport, storage, and distribution of raw foods susceptible to contamination (Perez et al., 2003; Elika, 2013; Elika, 2020).

The foods commonly related to disease outbreaks having Clostridium botulinum as the causal agent vary depending on the food, eating habits, hygiene conditions, conservation, and process conditions, and on the heat treatment they are subjected to. Generally, the foods associated to botulism are canned vegetables, cured or fermented meats (sausages), semi-preserved and canned fish, salted, fermented, cold-smoked fish and products packed under vacuum or modified atmospheres, spices, dairy products, raw fruits and vegetables, juices, and honey (Huss, 1997; Vásquez, 2003; Tornese et al., 2008; Santos e Oliveira, 2012; Leclair et al., 2013; Huertas-Caro et al., 2019; Elika, 2013; Martinez, 2020; Elika, 2020).

Research around the world has reported contamination of food by C. botulinum. For instance, Sevenier et al., (2012) carried out a study focused on the detection of bacteria and spores of thermophilic anaerobes associated with spoilage and pathogens such as C. botulinum on vegetables (carrots and green beans) used in the preparation of preserves. The researcher reported that from 316 raw vegetable samples, collected from 14 various French manufacturers, two were positive for spores of Clostridium botulinum that produces type B botulinum neurotoxin, and noting that $C$. botulinum is the reference pathogen in canned foods and that the risk contamination is controlled by good manufacturing practices. In addition to this, the inactivation of heat-resistant mesophilic bacteria can be verified by a commercial environmental stability and sterility test of the product after a prolonged incubation at $37^{\circ} \mathrm{C}$. Therefore, the control of bacteria in canned food will depend on the initial number of spores in the product and adjustment parameters of the thermal processes. Finally, the researches indicated that contamination in raw vegetables by $C$. botulinum types A and B are the main types described in these foods, being the type B the most common in Europe.

Chukwu et al. (2016) in a study of detection of Clostridium species in food (meat, vegetables, preserves, honey, milk and derivatives), commercialized in Lagos, Nigeria, pointed out that from 220 samples collected, most of the isolates of Clostridium spp., were obtained from vegetables (56\%), meat (34\%) and a lower proportion from canned foods $(6 \%)$ and dairy products $(4 \%)$. When isolating 50 species of Clostridium, being 29 of $C$. perfringens and 2 were toxigenic C. botulinum neurotoxins A producer, the latter in local spiced beef (Suya) that is commonly consumed in Nigeria, in addition to homemade yogurt bottled in the street. Therefore, poor hygiene measures in the production and marketing of food, and the origin of contamination from faecal material, environmental or food handlers were pointed out.

Shahcheraghi et al. (2013) reported a botulinum toxin detection study on a total of 1140 clinical and food samples from 21 Iranian provinces. Of the total of samples, 64 positives for botulism were identified and of these, 14 presented toxin type A, seven toxin type B, 22 toxin type E and seven toxin type AB. While in 14 samples, the type of toxin could not be identified. Foods such as locally made fish, meat and dairy are the foods most implicated in cases of type $\mathrm{E}$ and $\mathrm{A}$ botulism. On the other hand, various references have indicated that generally the contamination of fish and products and cases of botulism is mainly by C. botulinum type A, B, E and F (Huss, 1997; Sevenier et al., 2012; Leclair et al., 2013). 
For canned foods, and according to their acidity, which can be high $(\mathrm{pH}<4.6-3.7)$ or low ( $\mathrm{pH}>4.6)$, mesophilic and thermophilic species of the genera Clostridium and Bacillus are relevant in the industry when being involved in the decomposition (rancidity, thermophilic anaerobiosis and putrefaction) and sanitary conditions of food (Pelczar et al., 1982; Gomez-Sanchez, 2007). In the canning process the food is deposited in containers and sealed to be heated up to eliminate microorganisms and spores. In an adequate thermal process, the initial spore load, the time-temperature relationship, which depends on the type of food, density, $\mathrm{pH}$, and dimensions of the food container, must be considered. All of this is considered to generate the processing strategy and thermal treatment adequate to ensure the quality of the food that will have to remain stable indefinitely even without refrigeration (Madigan et al., 2004; Sevenier et al., 2012; Rabiela, 2015). The presence of spores in hermetically sealed canned food, plastic or glass containers that germinate in an anaerobic environment when the heat treatment is not adequate, their ingestion is a risk for getting botulism (Romero, 1999). Food in containers visibly altered by changes in internal pressure due to gas formation (bulges) should not be eaten. However, to the latter, it has been pointed out that the absence of gas is not a guarantee of consumption of a safe food (Madigan et al., 2004).

Among the general control and prevention actions throughout the food chain are: the implementation of good hygiene practices and control systems based on Hazard Analysis and Critical Control Points (HACCP), which contribute to reducing the number of microorganisms from various natural sources such as soil, water, and excrement. Likewise, it is important to comply with the microbiological criteria of raw materials during the processing and transformation of food, as well as the use of chemical preservatives such as salt, nitrites or nitrates in adequate concentrations, and control of thermal processes in time-temperature in canned foods to allow the destruction of vegetative forms and spores (Huss, 1998; Vasquez, 2003; Sevenier et al., 2012; Elika, 2013; Fuertes et al., 2014; Rabiela, 2015; Novoslavskij et al., 2016; Elika, 2020; ACSA - UAB, 2021). At household level, for handlers and end consumers, the recommendations to avoid foodborne diseases, including botulism are: 1. Cleaning: Wash hands, utensils, surfaces, fruits, and vegetables frequently; 2. Separation (avoid cross contamination), 3. Cooking (correct time and temperature), 4. Cooling (immediate refrigeration, proper defrosting, avoid danger zone $40^{\circ} \mathrm{F}$ to $140^{\circ} \mathrm{F}$ ) and 5. The use of water and safe raw materials (WHO, 2007; CDC, 2019).

Government actions and policies are also fundamental in food safety. The harmonization of laws between countries in different economic regions can increase the control of microbiological hazards in the food trade and improve safety levels (Masana, 2015). For instance, In regards of the regulation of food safety around the world for the different fishery and aquaculture products referring to Clostridium botulinum and toxins, countries such as Spain, in Europe, through the order of August 2, 1991 (BOE-A -1991-20734) of the Ministry of Health and Consumption for dried, salted, smoked and canned fish products, established the absence of microorganisms that grow and multiply, prior to pre-incubation tests, for thirty days, the microbiological limitations at $31^{\circ} \mathrm{C} \pm 1{ }^{\circ} \mathrm{C}$ and ten days at $44^{\circ} \mathrm{C}$, as well as the absence of botulinum toxin in the product. However, these limits were repealed by the royal decree 135/2010 (BOE-A-2010-3032) for transposing community regulations.

Food legislation in the European community includes different regulations focused on the context of hygiene and safety. Just to mention a few, there are the Regulation (EC) 178/2002, which establishes the principles and general requirements of food legislation, creates the European Food Safety Authority and procedures related to food safety are established and said regulation applies to all stages of the production, transformation and distribution of food and feed, but not to primary production for private use or to the domestic preparation, handling or storage of food for own consumption. The Regulation (EC) No 852/2004, which relatives to general rules in the hygiene of food products, is intended for food business operators, considered the main responsible for food safety and the need to guarantee food safety throughout the food chain involving the application of the principles of Hazard Analysis and Critical Control Points (HACCP).

The Regulation (EC) No 853/2004 establishes the specific hygiene standards for foods of animal origin, including fish, in different stages that include handling, transformation and conservation. The Regulation (EC) No 854/2004 establishes specific rules for the organization of official controls of products of animal origin destined for human consumption; these controls include audits of food business operators on good hygiene practices and procedures based on HACCP system, in addition to specific controls for fishery products. And the Regulation (EC) No 2073/2005 for food products where the microbiological criteria established for a range of products intended for human consumption are presented. Although this regulation does not establish microbiological limits to guarantee the safety of foods susceptible to being contaminated with Clostridium, it establishes that the competent authority may carry out sampling and analysis to detect and measure other 
microorganisms, their toxins, or metabolites, either to effects of verifying processes, in the case of foods that are suspected of being unsafe, or in the context of a risk analysis (Elika, 2020).

On the other hand, in Latin American countries such as Mexico, the safety of fish and products is regulated through compliance with different standards throughout the food chain, where in the case of primary production, the application of good aquaculture and fishing practices include Tilapia (García and Calvario, 2008; SENASICA, 2019). Regarding the processing and transformation stages, the products are regulated by the NOM-242-SSA1-2009 standard, focused on fresh, refrigerated, frozen and processed fish products, which include sanitary specifications and test methods for products. This rule stats that, for vacuum prepackaged, sterilized, pasteurized, and smoked products, Clostridium botulinum must be absent, as well as botulinum toxin. On the other hand, the NOM-128-SSA1-1994 standard establishes the application of a HACCP system in the industrial plant that processes fish products. The NOM-251-SSA1-2009 standard establishes the requirements and hygiene practices for the process of food, beverages, or food supplements, as well as the implementation of a quality assurance system such as the HACCP. Meanwhile, and for the case of foods packaged in hermetically sealed containers and subjected to heat treatment, including canned ones, the NOM-130-SSA1-1995 standard establishes the physical and microbiological sanitary provisions and specifications that the product must comply with according to the $\mathrm{pH}$, indicating that the presence of anaerobic mesophiles such as $C$. botulinum must be negative.

\subsection{Laboratory Analysis}

The traditional microbiological analysis in the laboratory, for the isolation and identification of bacteria, makes use of serial dilutions depending on the type of food and microorganism to be analyzed in the sample. It also establishes different phases in the analysis such as pre-enrichment, isolation in differential and selective media, biochemical identification and antigenic characterization and antimicrobial resistance, if necessary (Huertas-Caro, 2019). Sample collection presents a fundamental role in the detection and isolation of pathogens in food and its relationship with case studies or disease outbreaks. Food samples for analysis, except for unopened and bulky packaged ones, must be well identified and kept at $4{ }^{\circ} \mathrm{C}$ after collection, during transportation to the laboratory, and until analysis is complete.

Foods suspected of being associated with botulism should be collected as soon as possible including any remaining food known to be consumed by the patient within 36 hours. Any commercial food suspected of causing botulism should be reported to the corresponding food regulatory authority (Maslanka et al., 2013). To determine the hygienic quality of water and food intended for human use and consumption, the indicator of sulfite-reducing anaerobes is frequently used. This indicator consists of a bacterial group, associated with the genus Clostridium, with the property of reducing the sulfite ion to sulfide in the presence of ferric citrate or another heavy metal salt, forming characteristic black colonies (Gesche et al., 2003; ANAMAT, 2014; Campuzano et al., 2015). Therefore, the detection and enumeration of reducing Clostridium sulfite can be carried out by determining the presence of vegetative and sporulated forms, together or by the presence of sporulated forms only (ANAMAT, 2014). 
Within the standardized methodologies for the analysis of food samples for human and animal consumption and environmental samples, it is the ISO 15213 method for the count of sulfite-reducing bacteria in anaerobiosis (Figure 1) (ANMAT, 2014).

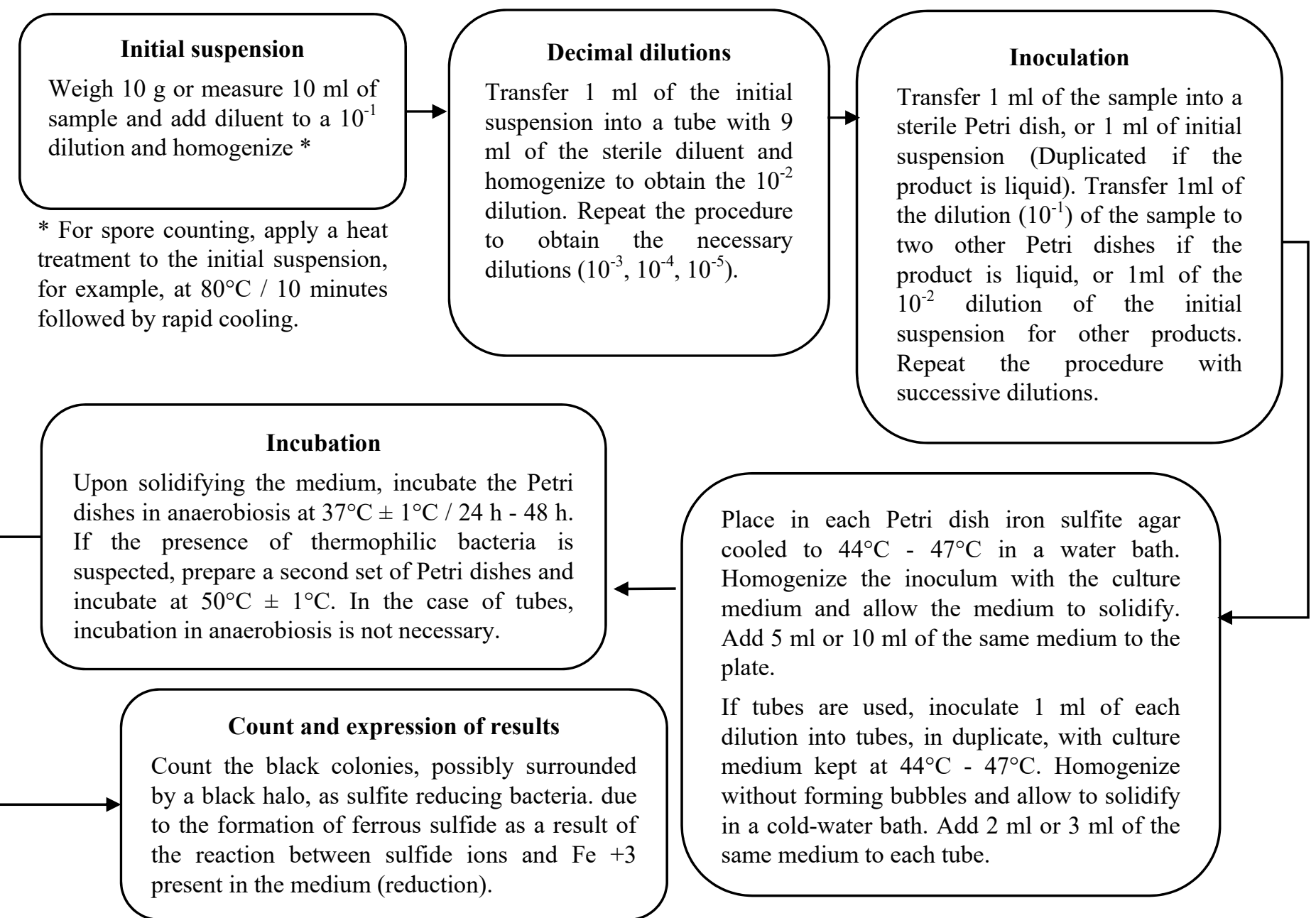

Figure 1. Method of detection and quantification of sulfite reducing anaerobes in food (ISO 15213:2003;

ANMAT, 2014)

Microbial detection and counting are carried out using an atmosphere absent of oxygen, culture media containing sodium sulfite, the microorganisms metabolize it exerting its reducing action, converting it into sulfide which, when acting on iron, forms iron sulfide and it shows a black color in colonies (ANAMAT, 2014).

In food, high counts of sulfite-reducing anaerobes are a sign of the presence of pathogens (Clostridium). In addition to possible deficiency in good manufacturing practices in the transformation process, low quality raw material, inadequate storage, and conservation conditions (ANAMAT, 2014; Campuzano et al., 2015).

For the quality of water for human use and consumption, anaerobic sulfite-reducing bacteria are also commonly used for the evaluation of water disinfection processes to prevent the transmission of diseases. These microorganisms are responsible for the deterioration producing odors and frequently blackening of the product that, by containing iron in its composition, the microorganisms can generate a precipitate of iron sulfide for its detection. There are methodologies to determine the sanitary quality of water and disinfection processes, this, through the microbial anaerobic sulfite reducing capacity based on the detection and enumeration of spores by Most Probable Number (MPN) and selective enrichment by the method ISO 6461-1 and ISO 6461-2 method by membrane filtration (Gesche et al., 2003).

For the case of detection of $C$. botulinum, there are several standardized analysis methods that use traditional microbiology. One of these methods is the one reported by Solomon and Timothy, (2017) present in the Bacteriological Analytical Manual (BAM) of the U.S. Food and Drugs Administration (FDA). The method involves the detection of viable $C$. botulinum cells and food toxicity through enrichment, isolation and culture 
selection phases using different culture media such as cooked meat medium, anaerobic egg yolk agar or both, Trypticase-Peptone- Glucose-Yeast extract (TPGY), broth or with Trypsin (TPGYT), anaerobic atmospheres, in addition to the mouse bioassay for $C$. botulinum toxin. Likewise, there is the method from the United States Department of Agriculture (USDA) and the Food Safety and Inspection Service (FSIS) for the detection of $C$. botulinum toxins in meat and products, where they also use mouse bioassays for toxins of the pathogen in culture or food (Cook et al., 1998). The Mexican regulation NOM-242-SSA1-2009 establishes the method for detect $C$. botulinum in fish samples and products based on culture using selective and differential media Clostridium botulinum Isolation agar (CBI), Meat Medium Cooked (CMM), Tryptone Peptone Glucose Yeast Extract Broth (TPGYEB), Tryptone Peptone Glucose Yeast Trypsin extract broth (TPGYT), calf liver agar, egg yolk agar, Eklund sporulation agar, anaerobic conditions, and demonstration of the toxin in mouse bioassay. Meanwhile, for fish and products hermetically packaged subjected to heat treatment, the standard NOM-242-SSA1-2009 and NOM-130-SSA1-1995 specify the microbiological analysis method to which the samples are subjected based on the $\mathrm{pH}$ end of the product, and involves the use of culture media (cooked meat broth, bromocresol purple glucose broth, acid broth, among others), and selective temperatures $\left(30^{\circ} \mathrm{C}, 35^{\circ} \mathrm{C}\right.$ and $\left.55^{\circ} \mathrm{C}\right)$, with the objective of determining the alteration and health risk caused by different microorganisms that survive heat treatment such as anaerobic mesophiles (Clostridium botulinum), anaerobic thermophiles, aerobic mesophiles, and aerobic thermophiles.

Other alternative or complementary methods to the detection of $C$. botulinum and toxins in food, unlike the physiological and biochemical characteristics of the culture and the mouse bioassay, the latter considered the gold standard method for detecting botulism, are the Immunological Essay Linked to Enzymes (ELISA), lateral flow immunoassays, electrochemiluminescence (ECL), endopeptidase assays, MALDI TOF mass spectrometry, Polymerase Chain Reaction (PCR), among others (Drevinek et al., 2012; Shahcheraghi et al., 2013; Solomon \& Timothy, 2017; Lopez-Villar, 2019; Yadav et al., 2019). For C. botulinum molecular identification is carried out through the Polymerase Chain Reaction (PCR) in its multiple variants and can be used in conjunction with mouse bioassays. The detection targets virulence genes encoding toxins such as toxin type A BoNT gene (A), toxin type B gene BoNT (B), toxin type E gene BoNT (E), toxin type F BoNT gene (F) and includes a previous stage of growth in an enrichment culture medium for vegetative cells or spores (Fach et al., 2008; Fenicia et al., 2011; Palomino-Camargo \& González-Muñoz, 2014; Chukwu et al., 2016; Solomon \& Timothy, 2017; Williamson et al., 2017). Likewise, molecular tools such as genomic sequencing, Pulsed-Field Gel Electrophoresis (PFGE), Multiple-Locus Variable-Number Tandem-Repeat Analysis (MLVA), Multilocus Sequence Typing (MLST), Amplified Fragment Length Polymorphism (AFLP) and Whole- Genome Single-Nucleotide-Polymorphism are used for phylogenetic and epidemiological studies of toxin-producing strains (Fillo et al., 2011; Raphael et al., 2014; Olsen et al., 2014; González-Escalona et al., 2014; Williamson et al., 2017).

\section{Conclusions}

Fish is considered a food of high nutritional quality essential in the diet of the human being. This food is widely produced and marketed around the world in different presentations like fresh whole, gutted, fillet, frozen, refrigerated, canned, among others. Tilapia is one of the finfish with the highest aquaculture production in the world. However, like any fish and products, it can be highly susceptible to deterioration and contamination along the food chain by microorganisms, many of them pathogens responsible for cases and outbreaks of food-borne diseases.

Clostridium botulinum is an anaerobic, sporulated pathogen responsible for the disease called alimentary botulism due to its growth and generation of botulinum toxin, which has serious consequences for the health of the consumer, being death the most severe.

Clostridium botulinum, in its vegetative or spore form, can be present as part of the microbiota, sediment or waters where fish live, or can contaminate fish destined for human consumption through air, water, soil, animals or humans due to bad practices of hygiene in handling and conservation. Therefore, actions to control and prevent botulism from fish and products are focused on the implementation of good hygiene practices in aquaculture and fishing production and transformation with HACCP systems, which include inspection of raw materials, adequate controls in processing and conservation, emphasizing thermal processes (time-temperature) for products that require it, such as the canning food that promote bacterial growth.

The development of food science and technology has made it possible to establish and develop different lines of research focused on processing and preservation, in which the characteristic of food safety must always be considered as essential in products. On the other hand, at present factors such as the demand for nutritious and 
safe food by a constantly growing population, global marketing, new food production technologies and changes in the population's eating habits have been related to a greater appearance of foodborne diseases. Therefore, it is necessary to generate and develop more research focused on the different technologies of food preservation and their relationship with mechanisms of survival, adaptation, virulence factors, and distribution of food pathogens including C. botulinum in order to guarantee food safety and public health.

\section{Interest Conflict}

The author has not conflict of interest in the development and publication of this document.

\section{References}

ACSA-UAB (2021). Mapa de peligros alimentarios. Clostridium botulinum. Retrieved from https://mapaperills.uab.cat/pdf/perills/115_Biobac-Cbotulinum_ES.pdf

Alerte, V., Cortés, A, S., Díaz, T., Janepsy, Vollaire Z., Jeannette, Espinoza, M. M. E., Solari, G. V., Cerda L. J., \& Torres H. M. (2012). Brotes de enfermedades transmitidas por alimentos y agua en la Región Metropolitana, Chile (2005-2010). Revista chilena de infectología, 29(1), 26-31. https://doi.org/10.4067/S0716-10182012000100004

ANMAT. (2014). Análisis microbiológico de los alimentos. Metodología analítica oficial. Microorganismos indicadores. Volumen 3. Asociación Nacional de Medicamentos, Alimentos y Tecnología Médica (ANMAT). Red Nacional de Laboratorios Oficiales de Análisis de Alimentos (RENALOA). Ministerio de salud. Presidencia de la nación. Argentina. Retrieved from https://www.anmat.gov.ar/renaloa/docs/analisis_microbiologico_de_los_alimentos_vol_iii.pdf

Baltazar, P. M. (2007). La Tilapia en el Perú: acuicultura, mercado, y perspectivas. Revista peruana de biología, 13(3), 267-273. https://doi.org/10.15381/rpb.v13i3.2355

BOE-A-1991-20734. Orden de 2 de agosto de 1991 por la que se aprueban las normas microbiológicas, los límites de contenido en metales pesados y los métodos analíticos para la determinación de metales pesados para los productos de la pesca y la acuicultura. Ministerio de Sanidad y Consumo. España. Retrieved from https://www.boe.es/buscar/doc.php?id=BOE-A-1991-20734\#: :text=Orden\%20de\%202\%20de\%20agosto,1 a\%20pesca\%20y\%201a\%20acuicultura

BOE-A-2010-3032. Real Decreto 135/2010, de 12 de febrero, por el que se derogan disposiciones relativas a los criterios microbiológicos de los productos alimenticios. Ministerio de la Presidencia. España. Retrieved from https://www.boe.es/diario_boe/txt.php?id=BOE-A-2010-3032

Bratz, P. D. E., \& Mallet, E. K. V. (2015). Toxina Botulínica Tipo A: abordagens em saúde. Revista Saúde Integrada, 8(15-16). Retrieved from https://core.ac.uk/download/pdf/229766158.pdf

Campuzano, S., Flórez, D. M., Ibarra, C. M., \& Sánchez, P. P. (2015). Determinación de la calidad microbiológica y sanitaria de alimentos preparados vendidos en la vía pública de la ciudad de Bogotá DC. Nova, 13(23), 81-92. https://doi.org/10.22490/24629448.1708

CDC. (2018). Seguridad de los alimentos. Microbios y enfermedades transmitidos por los alimentos. Centros para el Control y la Prevención de Enfermedades (CDC). Centro Nacional de Enfermedades Infecciosas Emergentes y Zoonóticas. División de Enfermedades Transmitidas por los Alimentos, el Agua y el Medioambiente. Retrieved from https://www.cdc.gov/foodsafety/es/foodborne-germs-es.html

CDC. (2019). Seguridad de los alimentos. Centros para el Control y la Prevención de Enfermedades (CDC). Centro Nacional de Enfermedades Infecciosas Emergentes y Zoonóticas. División de Enfermedades Transmitidas por los Alimentos, el Agua y el Medioambiente. Retrieved from https://www.cdc.gov/foodsafety/es/index.html

Cereser, N. D., Costa, F. M. R., Rossi Júnior, O. D., Silva, D. A. R. D., \& Sperotto, V. D. R. (2008). Botulismo de origem alimentar. Ciência Rural, 38(1), 280-287. https://doi.org/10.1590/S0103-84782008000100049

Chukwu, E. E., Nwaokorie, F. O., Coker, A. O., Avila-Campos, M. J., Solis, R. L., Llanco, L. A., \& Ogunsola, F. T. (2016). Detection of toxigenic Clostridium perfringens and Clostridium botulinum from food sold in Lagos, Nigeria. Anaerobe, 42, 176-181. https://doi.org/10.1016/j.anaerobe.2016.10.009

Cook, L. V., Lee Wei Hwa, Lattuada, C. P., \& Ransom, G. M. (1998). Methods for the detection of clostridium botulinum toxins in meat and poultry products. Chapter 14. USDA/FSIS Microbiology Laboratory Guidebook 3rd $\quad$ Edition/1998. Retrieved from https://corpora.tika.apache.org/base/docs/govdocs1/711/711224.pdf 
Cortés-Sánchez, A. D. J., Díaz-Ramírez, M., Sánchez-Mundo, M. L., Hernández-A. J., \& Barrón-Sosa, L. R. (2015). Foodborne diseases, probiotics and health. Asian Journal of Microbiology, Biotechnology \& Environmental Sciences, 17(3), 763-774. Retrieved from https://www.envirobiotechjournals.com/article_abstract.php?aid=6298\&iid=199\&jid=1

Dávalos Mecalco, S. G., Zamora Pantoja, D. R., Natividad, B. I., Tercero Alburo, J. J., Vázquez Salinas, C., \& Quiñones Ramírez, E. I. (2005). Alimentos marinos: tipificación y proceso de almacenamiento. Revista Digital Universitaria, 6(9), 2-11. $\quad$ Retrieved from https://ru.tic.unam.mx/tic/bitstream/handle/123456789/965/sep_art90.pdf?sequence=1\&isAllowed=y

De la Fuente Salcido, N. M., \& Corona, J. E. B. (2010). Inocuidad y bioconservación de alimentos. Acta universitaria, 20(1), 43-52. https://doi.org/10.15174/au.2010.76

Donoso, S., Gadicke, P., \& Landaeta, C. (2016). Zoonosis transmitted by food can affect its epidemiology, as a result of climate change and processes of globalization. Chilean journal of agricultural \& animal sciences, 32(2), 149-156. https://doi.org/10.4067/S0719-38902016000200008

Drevinek, M., Dresler, J., Klimentova, J., Pisa, L., \& Hubalek, M. (2012). Evaluation of sample preparation methods for MALDI-TOF MS identification of highly dangerous bacteria. Letters in applied microbiology, 55(1), 40-46. https://doi.org/10.1111/j.1472-765X.2012.03255.x

Duan, S., Zhou, X., Xiao, H., Miao, J., \& Zhao, L. (2019). Characterization of bacterial microbiota in tilapia fillets under different storage temperatures. Journal of food science, 84(6), 1487-1493. https://doi.org/10.1111/1750-3841.14630

EFSA and ECDC (European Food Safety Authority and European Centre for Disease Prevention and Control). (2018). The European Union summary report on trends and sources of zoonoses, zoonotic agents and food-borne outbreaks in 2017. EFSA Journal, 16(12), e05500. https://doi.org/10.2903/j.efsa.2018.5500

Elika. (2013). Clostridium. Fundación vasca para la seguridad alimentaria. Retrieved from https://datos.elika.eus/pdfs_agrupados/Documento87/Copia\%20de\%206.Clostridium.pdf

Elika. (2020). Clostridium. Fundación vasca para la seguridad alimentaria. Retrieved from https://seguridadalimentaria.elika.eus/clostridium/

Espinosa, L., Varela, C., Martínez, E. V., \& Cano, R. (2014). Brotes de enfermedades transmitidas por alimentos. España, 2008-2011 (excluye brotes hídricos). Boletín epidemiológico semanal, 22(11), 130-136. Retrieved from https://revista.isciii.es/index.php/bes/article/view/889/1070

Fach, P., Micheau, P., Mazuet, C., Perelle, S., \& Popoff, M. (2009). Development of real-time PCR tests for detecting botulinum neurotoxins A, B, E, F producing Clostridium botulinum, Clostridium baratii and Clostridium butyricum. Journal of Applied Microbiology, 107(2), 465-473. https://doi.org/10.1111/j.1365-2672.2009.04215.x

FAO. (2020). El estado mundial de la pesca y la acuicultura 2020. La sostenibilidad en acción. Roma. Organización de las naciones unidas para la agricultura y alimentación (FAO). https://doi.org/10.4060/ca9229es

Fenicia, L., Fach, P., Van Rotterdam, B. J., Anniballi, F., Segerman, B., Auricchio, B., \& Knutsson, R. (2011). Towards an international standard for detection and typing botulinum neurotoxin-producing Clostridia types $\mathrm{A}, \mathrm{B}, \mathrm{E}$ and $\mathrm{F}$ in food, feed and environmental samples: a European ring trial study to evaluate a real-time PCR assay. International journal of food microbiology, 145, S152-S157. https://doi.org/10.1016/j.ijfoodmicro.2011.02.001

Fillo, S., Giordani, F., Anniballi, F., Gorgé, O., Ramisse, V., Vergnaud, G., \& Lista, F. (2011). Clostridium botulinum group I strain genotyping by 15-locus multilocus variable-number tandem-repeat analysis. Journal of clinical microbiology, 49(12), 4252-4263. https://doi.org/10.1128/JCM.05396-11

Fuentes, M., Valladares, J., Grass, G., \& Pico, Y. (2011). Microbiota de interés para la salud pública de Oreochromis spp.(tilapia roja) cultivada en jaulas flotantes en agua dulce. Revista Cubana de $\begin{array}{lllll}\text { Investigaciones } & \text { Pesqueras, } & \text { 74-80. } & \text { Retrieved }\end{array}$ https://www.oceandocs.org/bitstream/handle/1834/4662/Mayel\%edn.pdf?sequence=1

Fuertes Vicente, H. G., Paredes López, F., \& Saavedra Gálvez, D. I. (2018). Buenas prácticas de manufactura y preservación a bordo: pescado inocuo. Big Bang Faustiniano, 3(4), 41-45. 
García Ortega, A., \& Calvario Martínez, O. (2008). Manual de Buenas Prácticas de Producción Acuícola de Tilapia para la Inocuidad Alimentaria. SENASICA. Centro de Investigación en Alimentación y Desarrollo, A.C. Unidad Mazatlán en Acuicultura y Manejo Ambiental. Retrieved from https://publico.senasica.gob.mx/?doc $=21457$

García-Pérez, J., Ulloa-Rojas, J. B., \& Mendoza-Elvira, S. (2021). Patógenos bacterianos y su resistencia a los antimicrobianos en los cultivos de tilapia en Guatemala. Uniciencia, 35(2), 1-17. https://doi.org/10.15359/ru.35-2.4

Gesche, E., Vallejos, A., \& Sáez, M. (2003). Eficiencia de Anaerobios sulfito-reductores como indicadores de calidad sanitaria de agua. Método de Número Más Probable (NMP). Archivos de medicina veterinaria, 35(1), 99-107. https://doi.org/10.4067/S0301-732X2003000100011

Gómez-Sánchez, A. (2007). Microorganismos de importancia en el tratamiento térmico de alimentos ácidos y de alta acidez. Temas Selectos Ing Aliment., 1, 24-32. Retrieved from https://www.udlap.mx/WP/tsia/files/No1-Vol-1/TSIA-1(1)-Gomez--Sanchez-2007.pdf

Gonzalez-Escalona, N., Timme, R., Raphael, B. H., Zink, D., \& Sharma, S. K. (2014). Whole-genome single-nucleotide-polymorphism analysis for discrimination of Clostridium botulinum group I strains. Applied and environmental microbiology, 80(7), 2125-2132. https://doi.org/10.1128/AEM.03934-13

Guerrero, J. A. (2016). Protocolo de Vigilancia en Salud Pública Enfermedades Transmitidas por Alimentos. Versión 02. Instituto Nacional de Salud (INS). República de Colombia. Retrieved from https://www.saludpereira.gov.co/medios/Protocolo_Enfermedades_Trans._por_alimentos2016.pdf

Haygood, A. M., \& Jha, R. (2018). Strategies to modulate the intestinal microbiota of Tilapia (Oreochromis sp.) in aquaculture: a review. Reviews in Aquaculture, 10(2), 320-333. https://doi.org/10.1111/raq.12162

Hernández Urzua, M. A. (2016). Microbiología de los alimentos: fundamentos y aplicaciones en ciencias de la salud. Primera edición. Editorial medica Panamericana. México D.F.

Huertas-Caro, C., Urbano-Cáceres, E., \& Torres-Caycedo, M. (2019). Molecular diagnosis: an alternative for the detection of pathogens in food. Revista Habanera de Ciencias Médicas, 18(3), 513-528. Retrieved from https://www.revhabanera.sld.cu/index.php/rhab/article/view/2352

Huss, H. H. (1998). El Pescado Fresco: Su Calidad y Cambios de su Calidad. FAO Documento técnico de pesca 348. Organización de las Naciones Unidas para la Agricultura y la Alimentación. Laboratorio Tecnológico. Ministerio de Pesca. Dinamarca. Retrieved from https://www.fao.org/3/v7180s/v7180s00.htm\#Contents

Huss, H. H. (1997). Aseguramiento de la calidad de los productos pesqueros. FAO Documento Técnico de Pesca. No. 334. Organización de las Naciones Unidas para la Agricultura y la Alimentación. (FAO). 174. Retrieved from https://www.fao.org/3/t1768s/T1768S00.htm\#TOC

INP. (2018). Acuacultura| Tilapia. Acuacultura comercial. Instituto Nacional de Pesca (INP). Gobierno de México. Retrieved from https:/www.gob.mx/inapesca/acciones-y-programas/acuacultura-tilapia

ISO 6461-1:1986. Water quality — Detection and enumeration of the spores of sulfite-reducing anaerobes (clostridia) - Part 1: Method by enrichment in a liquid medium. International Organization for Standardization (ISO).

ISO 6461-2:1986. Water quality - Detection and enumeration of the spores of sulfite-reducing anaerobes (clostridia) - Part 2: Method by membrane filtration. International Organization for Standardization (ISO).

Jácome, J., Quezada Abad, C., Sánchez Romero, O., Pérez, Julio E., \& Nirchio, M. (2019). Tilapia in Ecuador: paradox between aquaculture production and the protection of Ecuadorian biodiversity. Revista Peruana de Biología, 26(4), 543-550. https://doi.org/10.15381/rpb.v26i4.16343

Leclair, D., Fung, J., Isaac-Renton, J. L., Proulx, J. F., May-Hadford, J., Ellis, A., Ashton, E., Bekal, S., Farber, J. M., Blanchfield, B., \& Austin, J. W. (2013). Foodborne botulism in Canada, 1985-2005. Emerging infectious diseases, 19(6), 961-968. https://doi.org/10.3201/eid1906.120873

López Cabo, M., L. Romalde, J., Simal-Gandara, J., Gago Martínez, A., Giráldez Fernández, J., Bernárdez Costas, M., Pascual del Hierro, S., Pousa Ortega, Á., Manaia, C. M., Abreu Silva, J., \& Rodríguez Herrera, J. (2020). Identification of Emerging Hazards in Mussels by the Galician Emerging Food Safety Risks Network (RISEGAL). A First Approach. Foods, 9(11), 1641. https://doi.org/10.3390/foods9111641 
López-Villar, P. R. (2019). Clostridium botulinum: Metodología para la detección de la toxina botulínica en productos cárnicos. Grado en Nutrición Humana y Dietética. Facultad de medicina. Universidad de Valladolid. Retrieved from https://uvadoc.uva.es/handle/10324/37047

Madigan, T. M., Martinko, M. J., \& Parker, J. (2004). Brock. Biología de los microorganismos. Décima edición. Pearson Educación, S.A. Madrid. P.1096.

Martínez Angulo, L. D. (2020). Principales bacterias transmitidas por alimentos, preservación y control. Capítulo 4. In: Agrobiología. Una visión general y sus aplicaciones. Luis G. Ramírez Mérida (Ed.) (C) 2020 Mérida Publishers. https://doi.org/10.4322/mp.2020.001.04

Martínez-Cordero, F. J., Delgadillo, T. S., Sánchez-Zazueta, E., \& Cai, J. (2021). Tilapia aquaculture in Mexico: assessment with a focus on social and economic performance. FAO Fisheries and Aquaculture Circular No. 1219. Rome, FAO. https://doi.org/10.4060/cb3290en

Masana, M. O. (2015). Drivers for the emergence of biological hazards in foods. Revista Argentina de Microbiología, 47(1), 1-3. https://doi.org/10.1016/j.ram.2015.01.004

Maslanka, S. E., Solomon, H. M., Sharma, S., \& Johnson, E. A. (2013). Clostridium botulinum and its toxins. Compendium of methods for the microbiological examination of foods. Chapter 32. 1-11. APHA press. https://doi.org/10.2105/MBEF.0222.037

Monroy-Dosta, María del C., De Lara-Andrade, R., Castro-Mejía, J., Castro-Mejía, G., \& Coelho-Emerenciano, M. G. (2013). Microbiology community composition and abundance associated to biofloc in tilapia aquaculture. Revista de biología marina y oceanografia, 48(3), 511-520. https://doi.org/10.4067/S0718-19572013000300009

NOM-128-SSA1-1994. Bienes y servicios. Que establece la aplicación de un sistema de análisis de riesgos y control de puntos críticos en la planta industrial procesadora de productos de la pesca. Norma Oficial Mexicana. Retrieved from https://www.salud.gob.mx/unidades/cdi/nom/128ssa14.html

NOM-130-SSA1-1995. Bienes y servicios. Alimentos envasados en recipientes de cierre hermético y sometidos a tratamiento térmico. Disposiciones y especificaciones sanitarias. Norma Oficial Mexicana. Retrieved from https://www.salud.gob.mx/unidades/cdi/nom/130ssa15.html\#: :text=NORMA\%20Oficial\%20Mexicana $\% 2$ 0NOM\%2D130,que\%20dice\%3A\%20Estados\%20Unidos\%20Mexicanos

NOM-242-SSA1-2009. Productos y servicios. Productos de la pesca frescos, refrigerados, congelados y procesados. Especificaciones sanitarias y métodos de prueba. Norma Oficial Mexicana. Retrieved from https://dof.gob.mx/nota_detalle.php?codigo=5177531\&fecha=10/02/2011

NOM-251-SSA1-2009. Prácticas de higiene para el proceso de alimentos, bebidas o suplementos alimenticios. Norma Oficial Mexicana. Retrieved from https://www.dof.gob.mx/normasOficiales/3980/salud/salud.htm

Novoslavskij, A., Terentjeva, M., Eizenberga, I., Valciņa, O., Bartkevičs, V., \& Bērzin̄š, A. (2016). Major foodborne pathogens in fish and fish products: a review. Annals of microbiology, 66(1), 1-15. https://doi.org/10.1007/s13213-015-1102-5

Olsen, J. S., Scholz, H., Fillo, S., Ramisse, V., Lista, F., Trømborg, A. K., \& Blatny, J. M. (2014). Analysis of the genetic distribution among members of Clostridium botulinum group I using a novel multilocus sequence typing (MLST) assay. Journal of microbiological methods, 96, 84-91. https://doi.org/10.1016/j.mimet.2013.11.003

OMS. (2007). Manual sobre las cinco claves para la inocuidad de los alimentos. Departamento de Inocuidad de los Alimentos, Zoonosis y Enfermedades de Transmisión Alimentaria. Organización mundial de la salud (OMS). Retrieved from https://www.who.int/foodsafety/publications/consumer/manual_keys_es.pdf

OMS. (2021). Inocuidad de los alimentos. Datos y cifras sobre las enfermedades de transmisión alimentaria. Organización Mundial de la Salud (OMS). Retrieved from https://www.who.int/foodsafety/areas_work/foodborne-diseases/ferg_infographics/es/

Palomino-Camargo, C., \& González-Muñoz, Y. (2014). Técnicas moleculares para la detección e identificación de patógenos en alimentos: ventajas y limitaciones. Revista Peruana de Medicina Experimental y Salud Pública, 31, 535-546. https://doi.org/10.17843/rpmesp.2014.313.93

Pantaléon, V., Bouttier, S., Soavelomandroso, A. P., Janoir, C., \& Candela, T. (2014). Biofilms of Clostridium species. Anaerobe, 30, 193-198. http://doi.org/10.1016/j.anaerobe.2014.09.010 
Pelczar, Jr. M. J., Reid, D. R., \& Chan, E. C. S. (1982). Microbiología. Segunda edición en español. McGraw-Hill.

Pérez, H. P., Rubio, C., Pozuelo, M. R., Revert, C., \& Hardisson, A. (2003). Botulismo y toxina botulínica. Revista de Toxicología, 20(1), 8-12. Retrieved from https://www.redalyc.org/pdf/919/91920102.pdf

Rabiela Sotelo, M. del C. (2015). Higiene y conservación del pescado. Hospitalidad ESDAI, 28, 41-60. Retrieved from https://revistas.up.edu.mx/ESDAI/article/view/1482

Raphael, B. H., Shirey, T. B., Lúquez, C., \& Maslanka, S. E. (2014). Distinguishing highly-related outbreak-associated Clostridium botulinum type A (B) strains. BMC microbiology, 14(1), 192. https://doi.org/10.1186/1471-2180-14-192

Regulation (EC) No 178/2002 of the european parliament and of the council of 28 January 2002 laying down the general principles and requirements of food law, establishing the European Food Safety Authority and laying down procedures in matters of food safety. Official Journal of the European Communities. Retrieved from https:/eur-lex.europa.eu/legal-content/EN/TXT/PDF/?uri=CELEX:32002R0178\&from=ES

Regulation (EC) No 852/2004 of the European parliament and of the council of 29 April 2004 on the hygiene of foodstuffs. Official Journal of the European Union. Retrieved from https://eur-lex.europa.eu/LexUriServ/LexUriServ.do?uri=OJ:L:2004:139:0001:0054:es:PDF

Regulation (EC) No 853/2004 of the European parliament and of the council of 29 April 2004 laying down specific hygiene rules for on the hygiene of foodstuffs. Official Journal of the European Union. Retrieved from https://eur-lex.europa.eu/legal-content/EN/TXT/PDF/?uri=CELEX:32004R0853\&from=ES

Regulation (EC) No 854/2004 of the European parliament and of the council of 29 April 2004 laying down specific rules for the organization of official controls on products of animal origin intended for human consumption. Official Journal of the European Union. Retrieved from https://eur-lex.europa.eu/legal-content/EN/TXT/PDF/?uri=CELEX:32004R0854\&from=ES

Rodríguez Torrens, H., Barreto Argilagos, G., Sedrés Cabrera, M., Bertot Valdés, J., Martínez Sáez, S., \& Guevara Viera, G. (2015). The foodborne diseases, a health problem inherited and increased in the new millennium. REDVET. Revista Electrónica de Veterinaria, 16(8), 1-27. Retrieved from https://www.redalyc.org/pdf/636/63641401002.pdf

Rodríguez-Cavallini, E., Rodríguez, C., Gamboa, M. D. M., \& Arias, M. L. (2010). Microbiological evaluation of ready-to-eat foods manufactured by small Costa Rican industries. Archivos latinoamericanos de Nutrición, $\quad 60(2), \quad 179-183 . \quad$ Retrieved from https://ve.scielo.org/scielo.php?script=sci_arttext\&pid=S0004-06222010000200011

Romero Cabello, R. (1999). Microbiología y parasitología humana. Bases etiológicas de las enfermedades infecciosas. 2 edición. Editorial medica panamericana.

Romero-Jarero, J. M., \& Negrete-Redondo, M. P. (2011). Presencia de bacterias Gram positivas en músculo de pescado con importancia comercial en la zona del Caribe mexicano. Revista mexicana de biodiversidad, 82(2), 599-606. https://doi.org/10.22201/ib.20078706e.2011.2.465

Rosaura Farré Rovira, Francisco Martín Bermudo, Ana María Cameán Fernández, Alberto Cepeda Sáez, Mariano Domingo Álvarez, Antonio Herrera Marteache, Félix Lorente Toledano, Ma Rosario Martín de Santos, Emilio Martínez de Victoria Muñoz, M ${ }^{\mathrm{a}}$ Rosa Martínez Larrañaga, Antonio Martínez López, Cristina Nerín de la Puerta, Teresa Ortega HernándezAgero, Perfecto Paseiro Losada, Catalina Picó Segura, Rosa María Pintó Solé, Antonio Pla Martínez, Daniel Ramón Vidal, Jordi Salas-Salvadó, \& M $^{\mathrm{a}}$ Carmen Vidal Carou. (2011). Informe del Comité Científico de la Agencia Española de Seguridad Alimentaria y Nutrición (AESAN) sobre el botulismo infantil. Revista del comité científico, 14, 9-26. Retrieved from https:/www.elika.net/datos/articulos/Archivo745/Rev\%20CC\%20AESAN\%2014\%20Botulismo.pdf

SAGARPA. (2018). Atlas agroalimentario 2012-2018. Secretaria de agricultura, ganadería, desarrollo rural, pesca y alimentación (SAGARPA). Primera edición. Gobierno de México. Retrieved from https://nube.siap.gob.mx/gobmx_publicaciones_siap/pag/2018/Atlas-Agroalimentario-2018

Santos, J. S., \& Oliveira, M. B. P. P. (2012). Revisão: alimentos frescos minimamente processados embalados em atmosfera modificada. Brazilian Journal of Food Technology, 15(1), 1-14. https://doi.org/10.1590/S1981-67232012000100001 
SENASICA. (2019). Manuales de Buenas Prácticas Acuicolas. Servicio Nacional de Sanidad, Inocuidad y Calidad Agroalimentaria (SENASICA). Gobierno de México. Retrieved from https://www.gob.mx/senasica/documentos/manuales-de-buenas-practicas-pecuarias-acuicolas-y-pesqueras

Sevenier, V., Delannoy, S., André, S., Fach, P., \& Remize, F. (2012). Prevalence of Clostridium botulinum and thermophilic heat-resistant spores in raw carrots and green beans used in French canning industry. International Journal of Food Microbiology, 155(3), 263-268. https://doi.org/10.1016/j.ijfoodmicro.2012.02.009

Shahcheraghi, F., Nobari, S., Asl, H. M., \& Aslani, M. M. (2013). Identification of botulinum toxin type in clinical samples and foods in Iran. Archives of Iranian medicine, 16(11). Retrieved from https://www.aimjournal.ir/Article/565

Sheyin, A. N., \& Solomon, K. J. (2017). Endo Microbial Fauna of Tilapia spp. (Oreochromis niloticus) found in a Flowing Canal at Eden Garden and Park Utako, Abuja. Journal of Fisheries \& Livestock Production, 5(214), 1-8. https://doi.org/10.4172/2332-2608.1000214

Soares, K. M. D. P., \& Gonçalves, A. A. (2012). Qualidade e segurança do pescado. Revista do Instituto Adolfo Lutz (Impresso), $\quad 71(1), \quad 1-10 . \quad$ Retrieved from https://periodicos.ses.sp.bvs.br/scielo.php?script=sci_arttext\&pid=S0073-98552012000100001\&lng=e\&nr $\mathrm{m}=\mathrm{iso} \& \mathrm{tlng}=\mathrm{pt}$

Solomon Haim, M., \& Timothy Lilly, Jr. (2017). Clostridium botulinum. Bacteriological Analytical Manual (BAM). Chapter 17. U.S. Food and Drug Administration. Retrieved from https://www.fda.gov/food/laboratory-methods-food/bam-chapter-17-clostridium-botulinum

Soto Varela, Z., Pérez Lavalle, L., \& Estrada Alvarado, D. (2016). Bacterias causantes de enfermedades transmitidas por alimentos: una mirada en Colombia. Revista Salud Uninorte, 32(1), 105-122. https://doi.org/10.14482/sun.32.1.8598

Tornese, M., Rossi, M. L., Coca, F., Cricelli, C., \& Troncoso, A. (2008). Epidemiología y factores de riesgo asociados al botulismo de los alimentos y al botulismo infantil: Dónde y cuándo? Revista chilena de infectología, 25(1), 22-27. https://doi.org/10.4067/S0716-10182008000100004

Traverso, J., \& Avdalov, N. N. (2014). Beneficios del consumo de pescado. Dirección Nacional de Recursos Acuáticos (DINARA). INFOPESCA. Montevideo, Uruguay. Retrieved from https://www.infopesca.org/sites/default/files/complemento/publilibreacceso/1243//Benefiicios\%20para\%20 diinara.pdf

Vásquez de Plata, G. (2003). La contaminación de los alimentos, un problema por resolver. Salud UIS, 35(1), 48-57. Retrieved from https://revistas.uis.edu.co/index.php/revistasaluduis/article/view/728

WHO. (2021). Inocuidad de los alimentos. World Health Organization (WHO). Retrieved from https://www.who.int/es/news-room/fact-sheets/detail/food-safety

Williamson, CHD., Vazquez, A. J., Hill, K., Smith, T. J., Nottingham, R., Stone, N. E., Sobek, C. J., Cocking, J. H., Fernández, R. A., Caballero, P. A., Leiser, O. P., Keim, P., \& Sahl, J. W. (2017). Differentiating botulinum neurotoxin-producing clostridia with a simple, multiplex PCR assay. Applied and Environmental Microbiology, 83(18), e00806-17. https://doi.org/10.1128/AEM.00806-17

Yadav, S. K., Singh, M., \& Ponmariappan, S. (2019). ELISA Based Detection of Botulinum Neurotoxin Type 'F' in Red Meat and Canned Fish. Defence Life Science Journal, 4, 226-230. https://doi.org/10.14429/dlsj.4.14915

\section{Copyrights}

Copyright for this article is retained by the author(s), with first publication rights granted to the journal.

This is an open-access article distributed under the terms and conditions of the Creative Commons Attribution license (http://creativecommons.org/licenses/by/4.0/). 